\title{
PENGARUH SERBUK KUNYIT (CURCUMA DOMESTICA VALET) TERHADAP KECEPATAN REVERSIBILITAS KESUBURAN WANITA PASCA MENGGUNAKAN KB SUNTIK DMPA
}

\author{
Anita Indra Afriani, Nor Khayati, Julvainda Eka Priya Utama \\ STIKes Karya husada Semarang, Jl. Kompol R. SoekaNto No. 46 Semarang, 081226003885 \\ aanitaindra@yahoo.co.id
}

\begin{abstract}
ABSTRAK
KB Suntik DMPA (Depo Medroksi Progesterone Asetat) berisi depo medroksi progesterone asetat yang diberikan dalam suntikan tunggal $150 \mathrm{mg} / \mathrm{ml}$ secara intramuscular (IM) setiap 12 minggu. Keterbatasan KB suntik DMPA adalah reversibilitas kesuburan lambat. Tindakan untuk mengemblikan reversibilitas ini dilakukan dengan memberikan obat kimia dan herbal, salah satunya kunyit, sebab kunyit memiliki efek untuk melancarkan darah dan menambah energi, anti inflamasi, mempermudah persalinan, anti bakteri, memperlancar pengeluaran empedu, pelembab serta mengembalikan kesuburan wanita.. Tujuan penelitian ini untuk mengetahui pengaruh serbuk kunyit (Curcuma domestica Valet) terhadap kecepatan reversibilitas kesuburan wanita pasca menggunakan KB Suntik DMPA di PMB N Desa Sidigede Welahan Jepara. Metode penelitian menggunakan kuantitatif dengan rancangan two group post-test with control group design dengan kelompok intervensi di berikan serbuk kunyit dan kelompok kontrol tidak diberikan serbuk kunyit. Jumlah sampel sebanyak 16 responden untuk intervensi dan 16 untuk kontrol dengan accidental sampling. Analisis data menggunakan Uji Mann Whitney didapatkan nilai $\mathrm{p}$ value 0.000 berarti ada pengaruh serbuk kunyit terhadap kecepatan reversibilitas kesuburan wanita pasca menggunakan KB suntik DMPA. Sehingga di dapatkan kesimpulan serbuk mempercepat reversibilitas kesuburan wanita pasca menggunakan KB Suntik DMPA.
\end{abstract}

Kata kunci : KB suntik DMPA; reversibilitas kesuburan; serbuk kunyit

\section{THE EFFECT OF CURCUMA DOMESTICA VALET TOWARDS THE REVERSIBILITY OF WOMEN'S FERTILITY POST USING INJECTABLE CONTRACEPTIVES OF DMPA}

\begin{abstract}
Depo Medroxy Progesterone Acetate (DMPA) Injection contraception contains Depo Medroxy Progesterone Acetate which is given in a single injection of $150 \mathrm{mg} / \mathrm{ml}$ intramuscularly (IM) every 12 weeks. The limitation of DMPA injectable contraception is the slow fertility reversibility. The action to restore this reversibility is carried out by giving chemical and herbal medicines, one of which is turmeric, because turmeric has the effect of improving blood circulation and increasing energy, anti-inflammatory, facilitating childbirth, anti-bacterial, facilitating bile secretion, moisturizing and restoring female fertility. The purpose of this study was to determine the effect of turmeric powder (Curcuma domestica Valet) towards the reversibility of female fertility after using DMPA injectable contraception at N Maternal Clinic of Sidigede Welahan Village, Jepara. The research method used quantitative with two group post-test design with control group design, the intervention group was being given turmeric powder and the control group not being given turmeric powder. The numbers of samples were 16 respondents for the intervention and 16 for the control with accidental sampling. Data analysis used the Mann Whitney test obtained a $p$ value of 0.000 which means that there is an effect of turmeric powder on the rate of reversibility of female fertility after using DMPA injection contraception. So it can be concluded that the powder accelerates the reversibility of female fertility after using DMPA injectable contraception.
\end{abstract}

Key words: Injectable contraceptives DMPA; fertility reversibility; turmeric powder

Jurnal SMART Kebidanan is licensed under a Creative Commons Attribution-ShareAlike 4.0 International License. 


\section{LATAR BELAKANG}

Kontrasepsi suntik DMPA (depot medroksiprogesterone asetat) atau yang biasa disebut KB suntik 3 bulan mempunyai prevalensi paling tinggi, hal ini disebabkan $\mathrm{KB}$ suntik sangat praktis, efektif dan mudah (Handayani, Rohmi. 2010) . Kontrasepsi suntik DMPA ini adalah salah satu jenis kontrasespi suntikan yang hanya mengandung progestin saja dan disuntikkan setiap tiga bulan. Kontrasepsi suntik DMPA ini cukup aman dan sangat efektif dalam mencegah kehamilan apabila penyuntikannya dilakukan secara teratur sesuai jadwal yang telah ditentukan. Tingkat efektifitasnya cukup tinggi yaitu 0,3 kehamilan per 100 perempuan. Cara kerjanya adalah mencegah ovulasi, mengentalkan lender serviks sehingga menurunkan kemampuan penetrasi sperma, menjadikan selaput lender rahim tipis dan atrofi serta menghambat transportasi gamet oleh tuba (Handayani, Rohmi. 2010).

Penghentian penggunaan metode kontrasepsi suntik DMPA banyak yang mengeluh sulit atau lama untuk hamil lagi karena memang tidak seperti penggunaan pil atau AKDR (alat kontrasepsi dalam rahim), pengembalian kesuburan lebih cepat setelah penghentian penggunaan pil atau AKDR yaitu rata-rata 2 bulan, sedangkan setelah penghentian penggunaan suntik DMPA memerlukan waktu rata-rata 4-10 bulan. Bahkan ada beberapa wanita yang sampai bertahun-tahun menunggu kehamilan pasca penggunaan kontrasepsi tersebut (Handayani, Rohmi. 2010).

Kembalinya tingkat kesuburan adalah salah satu hal yang perlu mendapat perhatian setelah penggunaan kontrasepsi. Keterlambatan kesuburan setelah penyuntikan DMPA bukanlah disebabkan oleh terjadinya kelainan atau kerusakan organ genetalia, melainkan karena masih adanya pelepasan gestagen (hormone progesterone) yang terusmenerus dari depo yang terbentuk di tempat suntikan. Masa subur biasanya terjadi 14 hari sebelum hari pertama haid berikutnya. Pada masa subur terjadi ovulasi yaitu mengeluarkan sel telur yang sudah matang dan siap dibuahi oleh sperma. Jadi jika saat masa subur seorang wanita melakukan hubungan seksual dan kualitas sperma baik maka bisa terjadi pertemuan antara sel telur dengan sperma sehingga terjadi konsepsi. Dengan demikian siklus haid merupakan indicator pertama kesuburan wanita (Handayani, Rohmi. 2010).

Hasil studi pendahuluan di lokasi penelitian diketahui jumlah kunjungan pasien yang mengalami reversibilitas kesuburan yang lambat pasca menggunakan KB suntik DMPA pada bulan Oktober-Nopember 2019 sebanyak 34 orang. Penanganan untuk reversibilitas kesuburan yang lambat pasca menggunakan KB suntik DMPA di lokasi penelitian adalah dengan pemberian pil KB. Akan tetapi pemberian terapi pil KB mempunyai efek samping pusing dan mual sehingga banyak pasien tidak nyaman dengan terapi tersebut. Pemberian terapi pil KB jangka panjang juga memiliki efek samping, seperti nyeri payudara, pendarahan vagina, dan kanker payudara. Tindakan lain yang alami, mudah, dan efektif adalah dengan pemberian terapi SERBUK kunyit.

Kunyit (Curcuma domestica Valet) merupakan salah satu tanaman obat yang banyak memiliki manfaat dan banyak ditemukan di wilayah Indonesia. Kunyit memiliki efek farmakologis untuk melancarkan darah dan menambah energi, anti inflamasi, mempermudah persalinan, anti bakteri, memperlancar pengeluaran empedu, pelembab serta mengembalikan kesuburan wanita. Penelitian membuktikan bahwa infusa rimpang C. domestica bermanfaat terhadap masalah menstruasi, hal ini dikarenakan senyawa fitosterol berupa kampesterol, $\beta$-sitosterol, dan stigmasterol. Senyawa fitosterol merupakan precursor pembentukan hormone seks, salah satunya hormone estrogen. Estrogen mempengaruhi pertumbuhan dan proliferasi duktus kelenjar mammae dan mempengaruhi endometrium untuk proses menstruasi. Estrogen menyebabkan penebalan dinding endometrium dan lapisan epitel pipih berlapis vagina. Menstuasi normal terjadi akibat turunnya kadar progesteron dari endometrium yang kaya estrogen. Kandungan fitosterol pada kunyit dosis 100 gram sebanyak 0,0598\%. (Hartati \&Balittro, 2013). 
Tujuan penelitian ini untuk mengetahui pengaruh serbuk kunyit (Curcuma domestica Valet) terhadap kecepatan reversibilitas kesuburan wanita pasca menggunakan KB Suntik DMPA di PMB N Jepara.

\section{METODE}

Penelitian ini menggunakan jenis penelitian kuantitatif dengan desain Two Group Post test With control Design. Sampel dalam penelitian ini adalah ibu yang memakai KB suntik DMPA $>3$ tahun dan mengalami masalah reversibilitas pasca penggunaan KB suntik DMPA setidaknya 3 bulan tanpa menggunakan $K B$ sambungan, dengan jumlah sampel sebanyak 32 responden, yang dibagi menjadi 16 resoonden pada kelompok intervensi dan 16 responden pada kelompok kontrol.

Tehnik pengambilan sampel pada penelitian ini adalah dengan Accidental Sampling dengan memlihi responden berdasarkan kedatangan untuk yang datang dengan nomor ganjil dijadikan intervensi dan nomor genap dijadikan kontrol. Pada kelompok intervensi diberikan 60 bungkus serbuk kunyit masing-masing 15 gram untuk diminum 2 kali sehari yang dilarutkan dalam $200 \mathrm{ml}$ air dilakukan selama 30 hari atau sampai menstruasi (terhitung sejak awal menjadi responden) (Izzaty, Nindi. 2017). Pada kelompok kontrol responden tidak diberikan serbuk kunyit dan menunggu sampai datang menstruasi. Analisis bivariat menggunakan uji Mann Whitney. Etik dalam penelitian ini menggunakan informed consent, Anonim, Confidentiality, Nonmaleficence, Beneficence, dan clearance.

\section{HASIL}

Hasil penelitian digambarkan dalam tabel berikut ini;

Tabel 1 Diskripsi Kecepatan Reversibilitas Kesuburan Wanita Pasca Menggunakan KB Suntik DMPA

\begin{tabular}{lccccc}
\hline Kelompok & $\mathrm{n}$ & Mean & Median & SD & $\begin{array}{c}\text { Min- } \\
\text { Max }\end{array}$ \\
\hline intervensi & 16 & 14,3 & 13,5 & 3,557 & $10-21$ \\
\hline Kontrol & 16 & 51,06 & 53,0 & 7,104 & $34-60$
\end{tabular}

Tabel 1 menunjukkan kecepatan reversibilitas kesuburan responden pasca menggunakan KB suntik DMPA pada kelompok intervensi sebanyak 16 responden adalah paling cepat hari ke 10 dan paling lama hari ke 21. Sedangkan pada kelompok kontrol kecepatan reversibilitas kesuburan responden pasca menggunakan KB suntik DMPA sebanyak 16 responden adalah paling cepat hari ke 34 dan paling lama hari ke 60 .

Tabel 2. Analisis Perbedaan Kecepatan Reversibilitas Kesuburan Wanita Pasca Menggunakan KB Suntik DMPA ( $n=32)$

\begin{tabular}{ccc}
\hline Kelompok & Mean Rank & p value \\
\cline { 1 - 1 } intervensi & 8,50 & \\
\cline { 1 - 2 } Control & 24,50 & 0.000 \\
\hline
\end{tabular}

Tabel 2 diketahui bahwa hasil analisis statistik dengan uji Mann Whitney didapatkan nilai mean rank kelompok intervensi adalah 8,50 hari dan kelompok kontrol adalah 24,50 hari yang artinya ada perbedaan kecepatan reversibilitas kesuburan wanita pasca menggunakan KB suntik DMPA. Hasil analisa Mann Whitney didapatkan nilai $p$ value 0.000 sehingga dapat disimpulkan bahwa Ha diterima yang berarti ada pengaruh serbuk kunyit (Curcuma domestica Valet) terhadap kecepatan reversibilitas kesuburan wanita pasca menggunakan KB suntik DMPA .

\section{PEMBAHASAN}

Hasil penelitian menunjukkan bahwa pada kelompok yang di berikan serbuk kunyit sebanyak 15 gram dengan diberikan 2 kali sehari pagi dan sore dengan diseduh $200 \mathrm{ml}$ air lebih cepat mengalami reversibilitas kesuburan di bandingkan dengan kelompok kontrol (tanpa di berikan serbuk kunyit). Keterlambatan Reversibilitas kesuburan pasca menggunakan KB suntik DMPA disebabkan karena progesteron dalam komponen DMPA menekan LH sehingga endometrium menjadi lebih dangkal dan atrofis dengan kelenjar yang tidak aktif. Disamping itu kunyit memiliki efek farmakologis untuk mengembalikan kesuburan 
wanita. Mekanisme kerja KB suntik adalah dengan mencegah ovulasi, mengentalkan lender serviks sehingga menurunkan kemampuan penetrasi sperma, menjadikan selaput lender rahim tipis dan atrofi, dan menghambat transportasi gamet oleh tuba (Suzanne, Everett. 2012).

Efek progesterone dalam KB suntik DMPA mengakibatkan tidak terjadinya ovulasi dan selaput lender rahim tipis dan atrofi sehingga menyebabkan tidak terjadinya menstruasi. Estrogen yang terkandung dalam serbuk kunyit (Curcuma domestica Valet) memiliki pengaruh terhadap selaput rahim untuk mengeluarkan darah menstruasi. Dalam keseimbangan yang tertentu menyebabkan ovulasi, dan pada akhirnya penurunan kadarnya mengakibatkan disintegrasi endometrium dan terjadilah menstruasi (Izzaty, Nindi. 2017).

Sedangkan pada kelompok kontrol tanpa diberikan kunyit reversibilitas kesuburannya lebih lambat karena masih ada depot progesterone dalam otot dan tanpa diberikan terapi estrogen sebagai penyeimbang hormon progesterone sehingga kembalinya menstruasi lebih lambat. Salah satu keterbatasan KB suntik DMPA adalah reversibilitas kesuburan yang lambat. Depo provera atau disingkat DMPA adalah berisi depo medroksi progesterone asetat dan diberikan dalam suntikan tunggal $150 \mathrm{mg}$ secara intra muscular setiap 12 minggu. KB suntik DMPA adalah KB dengan dosis progesterone paling tinggi dan diberikan secara intramuscular dengan sistem Depo atau disimpan di bawah otot. Timbunan obat yang disimpan di bawah otot diserap oleh tubuh secara perlahan-lahan dan lama. Hal inilah yang menyebabkan KB suntik DMPA reversibilitas kesuburannya lambat. Reversibilitas kesuburan yang lambat pasca menggunakan KB suntik DMPA bukan karena terjadinya kerusakan/kelainan pada organ genitalia, melainkan karena belum habisnya pelepasan obat suntikan dari deponya (tempat suntikan) (Hartanto. 2014).

Hasil penelitian di dukung dengan penelitian Rohmi Handayani tahun 2010 bahwa KB suntik DMPA menyebabkan reversibilitas kesuburan lambat. Lama penggunaan KB suntik DMPA pada wanita ex-akseptor KB suntik DMPA di wilayah Kota Administratif Purwokerto rata-rata adalah 25,39 Bulan sedangkan lama kembalinya kesuburan pada wanita exakseptor KB suntik DMPA rata-rata adalah 8,82 Bulan.

\section{KESIMPULAN DAN SARAN}

Pemberian serbuk kunyit (curcuma Domestic Valet) dengan berat 15 gram yang di konsumsi 2 kali sehari dalam 30 hari lebih efektif mengembalikan reversibilitas kesuburan wanita pasca menggunakan KB suntik DMPA dibandingkan dengan kelompok yang tidak di berikan serbuk kunyit. Diharapkan ibu pasca menggunakan KB suntik DMPA yang menginginkan reversibilitas kesuburannya kembali cepat atau akan melakukan program kehamilan dapat menggunakan terapi non farmakologi berupa konsumsi serbuk kunyit ( Curcuma domestica Valet).

\section{REFERENSI}

Handayani, Rohmi. (2010). Hubungan Lamanya Pemakaian Kontrasepsi Suntik DMPA Dengan Kembalinya Kesuburan Pada Post Akseptor KB Suntik DMPA. Bidan Prada : Jurnal IImiah Kebidanan, Vol. 1 No. 1 Edisi Desember 2010.

Hartati \&Balittro, (2013). Khasiat Kunyit Sebagai Obat Tradisional dan Manfaat Lainnya. Warta Penelitian dan Pengembangan Tanaman Industri. Jurnal Puslitbang Perkebunan. 19 : 5-9.

Suzanne, Everett. (2012). Buku Saku Kontrasepsi dan Kesehatan Seksual Reproduktif. - Ed.2. EGC, Jakarta.

Izzaty, Nindi. (2017). Terapi Amenore Sekunder Dengan Akupunktur Serta Herbal Kunyit Dan Kelabet. JournalofVocationalHealthStudies. www.e journal.unair.ac.id/index.php/JVHS. JournalofVocationalHealthStudies 01 (2017): 2731. diakses pada tanggal 28 Desember 2019.

Hartanto. (2014). Keluarga Berencana dan Kontrasepsi. Pustaka Sinar Harapan. Jakarta. 